\title{
Partial characterization and comparison of cell wall proteinases from 5 strains of Streptococcus lactis
}

\author{
Véronique MONNET, D. LE BARS, E. NEVIANI * and J.C. GRIPON \\ I.N.R.A., Laboratoire de Biochimie et Technologie laitières \\ 78350 Jouy-en-Josas (France) \\ * Present address : Istituto Sperimentale Lattiero-Caseario, 20075 Lodi, Milano (Italy)
}

\section{Summary}

Cell wall proteinases from 5 strains of Streptococcus lactis including one S. lactis subsp. diacetylactis were compared and partially characterized. They shared some common enzymatic features: only one activity optimum at $30-40^{\circ} \mathrm{C}$, at $\mathrm{pH} 5.5-6$ on casein and 4-4.5 on haemoglobin. Crude cell wall extracts from the S. lactis strains were fully inhibited by DFP, but this inhibition was only partial for the $S$. lactis subsp. diacetylactis strain. Electrophoregrams of $\alpha_{\mathrm{s} 1}, \beta$ and $\mathrm{K}$-casein hydrolysates obtained with the cell-wall extracts of these strains were quite similar for each protein substrate. $\beta$-casein was preferentially broken down; $\alpha_{\mathrm{s} 1}$ and $\mathrm{K}$-caseins were hydrolysed to a lesser extent.

The production of proteolytic cell-wall activity was highly affected by the culture medium. The higher the peptide and/or calcium content of the medium, the lower the release of cell-wall proteinase.

Key words: Streptococcus lactis - Cell wall - Proteinase.

\section{Résumé}

Caractérisation partielle et comparaison des protéases de la paroi de 5 souches de Streptococcus lactis

Les protéases de paroi de 5 souches de Streptococcus lactis dont une de $S$. lactis subsp. diacetylactis sont comparées et partiellement caractérisées. Pour les cinq souches, un seul optimum d'activité est mis en évidence à $30-40{ }^{\circ} \mathrm{C}$, à pH $5,5-6$ sur la caséine et 4-4,5 sur l'hémoglobine. Les extraits bruts de paroi des souches de $S$. lactis sont totalement inhibés par le DFP, mais cette inhibition n'est que partielle pour la souche de $S$. lactis subsp. diacetylactis. Les schémas d'électrophorèses des hydrolysats des caséines $\alpha_{\mathrm{s} 1}, \beta$ et $\mathrm{K}$ par les extraits de paroi de ces souches sont très similaires pour chacun des substrats. La caséine $\beta$ est préférentiellement hydrolysée; les caséines $\alpha_{81}$ et $\mathrm{K}$ sont aussi attaquées mais plus faiblement.

Le milieu de culture des cellules influe fortement sur la production d'activité protéolytique de paroi. Plus la concentration en peptides et/ou en calcium du milieu est élevée, plus le relagarge des protéases de paroi est faible.

Mots clés : Streptococcus lactis - Paroi - Protéase. 


\section{Introduction}

The existence of a proteolytic activity in the cell-wall of lactic acid bacteria was evidenced in S. lactis in 1974 by THomAs et al. This proteolytic activity is essential for cell growth as it releases peptides used as such by the cell or after hydrolysis by cell-wall or membrane peptidases (EXTERKATE, 1976; THOMAS and MrLls, 1981). Furthermore, it was found that cell-wall proteinases play an important role in cheese technology because they are able to release bitter peptides (Mills and THOMAs, 1980).

Several studies on $S$. cremoris and $S$. lactis strains have revealed the existence of a complex enzyme system. Using different methods, up to 4 distinct components have been described in this cell-wall associated proteolytic system (Hugenholtz et al., 1984 ; Cliffe and LAW, 1985). From activity measurements at different temperature and $\mathrm{pH}$ values, ExTERKATE $(1975,1976)$ evidenced three differents proteinases in crude cell-wall extracts of milk-grown $S$. cremoris. The proteinase equipments of the tested strains were different, including one, two or three enzymes. Such a comparison has never been performed in the case of $S$. lactis. This paper reports the characterization of the cell-wall associated proteinases of $5 \mathrm{~S}$. lactis strains including one strain of $S$. lactis subsp. diacetylactis.

The influence of culture medium composition and physiological age of cells on the production of these proteinases was also studied.

\section{Material and methods}

\section{A. Cultures}

Strains of S. lactis NCDO 606, NCDO 763 and NCDO 823 were obtained from the National Collection of Dairy organisms (Reading, Great Britain). Strains of S. lactis CNRZ 261 and CNRZ 377 came from the collection of the Research Center of INRA (Jouy-en-Josas, France).

Cells were grown in a low-heat milk (NILAC, NIZO, Netherlands) as described by Mills and Thomas (1978) or in M17 medium (TERZAGHI and SANDINE, 1975), or in a commercial UHT milk. Cell growth at $30^{\circ} \mathrm{C}$ was assessed by $\mathrm{pH}$ and optical density (O.D.) measurements. Optical density was determined in conditions which allow solubilisation of casein micelles and prevent bacterial cells aggregation : $1 / 10$ dilution of milk in $0.2 \%$ EDTA, $\mathrm{pH} 12$ (THOMAs and TuRner, 1977). Bacteria were harvested by centrifugation at the end of the exponential phase and washed twice in $0.05 \mathrm{M}$ sodium glycerophosphate buffer, $\mathrm{pH} \mathrm{7}$, at $4^{\circ} \mathrm{C}$ in the presence of $20 \mathrm{mM} \mathrm{CaCl}_{2}$; calcium and a low temperature prevented the release of cell-wall proteinases (Mills and THOMAs, 1978). 


\section{B. Proteinase extraction}

The centrifuged cells were resuspended three successive times in $50 \mathrm{mM}$ triethanolamine buffer, $\mathrm{pH} 7$, containing $0.2 \mathrm{mM}$ 1-6 diphosphate fructose (1/10 of the culture volume). These buffer conditions were required for estimating lysis by lactate dehydrogenase ( $\mathrm{LDH}$ ) assay according to the method of Thomas (1975). Each incubation lasted $1 \mathrm{~h}$ and was carried out at $25^{\circ} \mathrm{C}$ in the absence of calcium. The three crude extracts were then filtered $(0.22 \mu \mathrm{m}$ filters, Millipore, Bedford, U.S.A.). Protein determination were carried out by the method of Bradford (1976); protein content of the crude extract being complex and unknown, an average of the values obtained with ovalbumin and serumalbumin was arbitrarily choosen as standard.

\section{Proteolytic activity assay}

Proteolytic activity was measured on ${ }^{14} \mathrm{C}$ labeled casein or haemoglobin according to the method of DonNelly et al. (1980). The specific activity of these substrates was 43.5 and $80 \mathrm{mCi} / \mathrm{mM}$, respectively and the final substrate concentration was $0.05 \%$. When nothing else is mentioned, the incubation took place at $\mathrm{pH} 6.0$ and $35^{\circ} \mathrm{C}$ and the reaction was stopped by addition of TCA to $6 \%$, final concentration. The release of TCA-soluble radioactivity was linear with time until it reaches $10 \%$ of the initial radioactivity of the labeled casein substrate. One proteolytic unit was the enzyme activity which released $1 \%$ of the initial radioactivity in the TCA-soluble fraction after $10 \mathrm{~min}$ incubation. For each experiment, it has been checked that no spontaneous hydrolysis of casein (without any enzymic extract) occurred.

\section{Electrophoresis}

Enzymatic digests of whole or purified caseins were studied by electrophoresis on agarose acrylamide gels according to URIEL's method (1966) modified by GRIPON et al. (1975).

\section{Results and discussion}

\section{A. Preparation of crude cell-wall extracts}

The five $S$. lactis were grown on low-heat milk. The growth curve shapes were the same for the different strains, but the amounts of proteinase released per O.D. unit and thus per cell were clearly different (table I). The amounts of cell-wall associated proteinases produced by strains CNRZ 377, NCDO 606 and NCDO 763 were equivalent while NCDO 823 (a S. lactis subsp. diacetylactis strain) seemed to release more activity and CNRZ 261 less.

The extent of cell lysis occurring during extraction was shown to be below $1 \%$ by $\mathrm{LDH}$ determination in the extracts. 


\section{TABLE I}

Growth and cell wall proteinase production parameters of five strains of $\mathrm{S}$. lactis

Paramètres rendant compte de la croissance et de la production de protéases de paroi de cinq souches de S. lactis

\begin{tabular}{|c|c|c|c|c|c|}
\hline $\begin{array}{c}\text { STRAIN } \\
\text { PARAMETERS }\end{array}$ & CNRZ 261 & CNRZ 377 & NCDO 606 & NCDO 763 & NCDO 823 \\
\hline INITIAL pH & 7.26 & 7.02 & 7.15 & 7.15 & 7.00 \\
\hline FINAL pH & 6.37 & 5.86 & 6.03 & 6.27 & 6.04 \\
\hline$\Delta \mathrm{pH}$ & 0.89 & 1.16 & 1.12 & 0.88 & 0.96 \\
\hline INITIAL O.D. & 0.14 & 0.17 & 0.09 & 0.16 & 0.17 \\
\hline FINAL 0.0 . & 0.45 & 0.57 & 0.44 & 0.54 & 0.62 \\
\hline$\Delta$ o.D. & 0.31 & 0.4 & 0.35 & 0.38 & 0.45 \\
\hline $\begin{array}{l}\text { CULTURE TIME } \\
\text { (HOURS) }\end{array}$ & 4.5 & 6 & 6 & 5.5 & 4.75 \\
\hline $\begin{array}{c}\text { TOTAL ACTIVITY } \\
\text { UNITS }\end{array}$ & 14815 & 34285 & 26493 & 33600 & 56160 \\
\hline $\begin{array}{l}\text { ACTIVITY UNITS/ } \\
\Delta \text { O.D. }\end{array}$ & 47790 & 85712 & 75694 & 88421 & 124800 \\
\hline
\end{tabular}

\section{B. Characterization of cell-wall crude extracts}

For the five tested extracts, only one activity optimum was detected, at pH 5.5-6 on casein and 4-4.5 on haemoglobin (fig. 1 and 2). Two of the three cell-wall proteinases found by EXTERKATE $(1975,1976)$ in $S$. cremoris crude extracts were also more active at acid $\mathrm{pH}$. This feature was confirmed for two cell wall proteinases purified from S. cremoris (GeIs et al., 1985) and $S$. lactis (MonNET et al., 1986), respectively. One optimal temperature of action was evidenced between $30^{\circ} \mathrm{C}$ and $40^{\circ} \mathrm{C}$ for all the five strains (fig. 3 ).

The effect of different inhibitors on the crude cell-wall extracts was tested. Serine proteinase inhibitors proved to be particularly efficient. However, the $S$. diacetylactis strains NCDO 823 was only partially inhibited by diisopropyl fluorophosphate (DFP) while a total inhibition was observed in the four $S$. lactis strains. Copper (II) was fully inhibitory on the five extracts. The effect of other compounds was less marked and variable according to the extracts (table II). Thomas et al. (1974) only tested some inhibitors on S. lactis cell wall crude extracts and found an almost total inhibition by EDTA suggesting the presence of a different enzyme. On the other hand, an inhibition similar to that we observed in the presence of DFP was obtained with purified proteinases (GEIS et al., 1985 ; MonNet et al., 1986). 


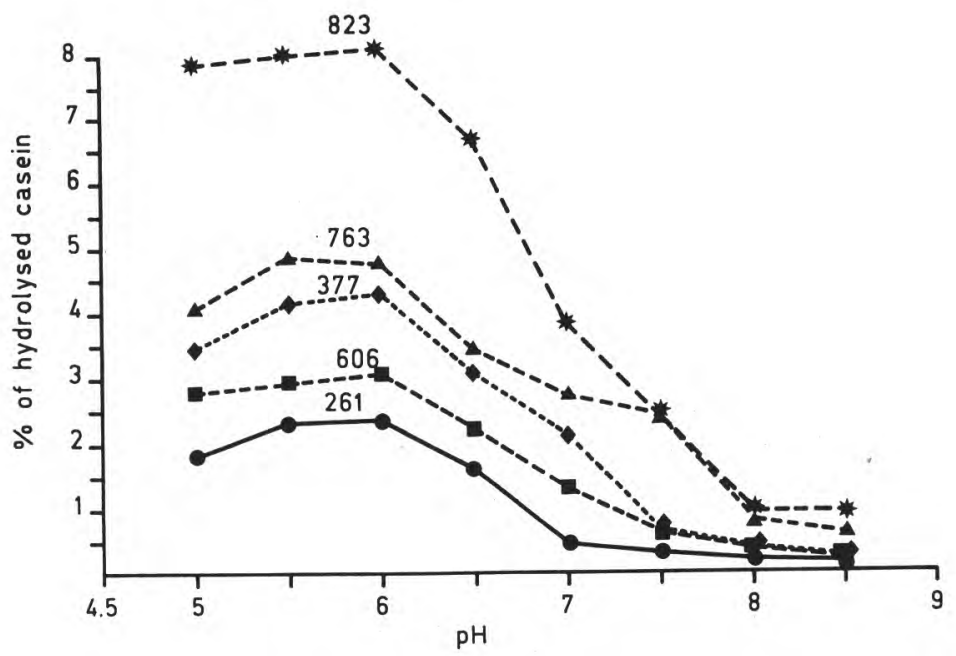

Fig. 1

pH optima at $35^{\circ} \mathrm{C}$ for the proteolytic activity of cell wall crude extracts from five strains of $\mathrm{S}$. lactis using ${ }^{14} \mathrm{C}$-casein as substrate.

pH optima d'activité protéolytique des extraits bruts de paroi des cinq souches de S. lactis en utilisant la ${ }^{14} \mathrm{C}$-caséine comme substrat.

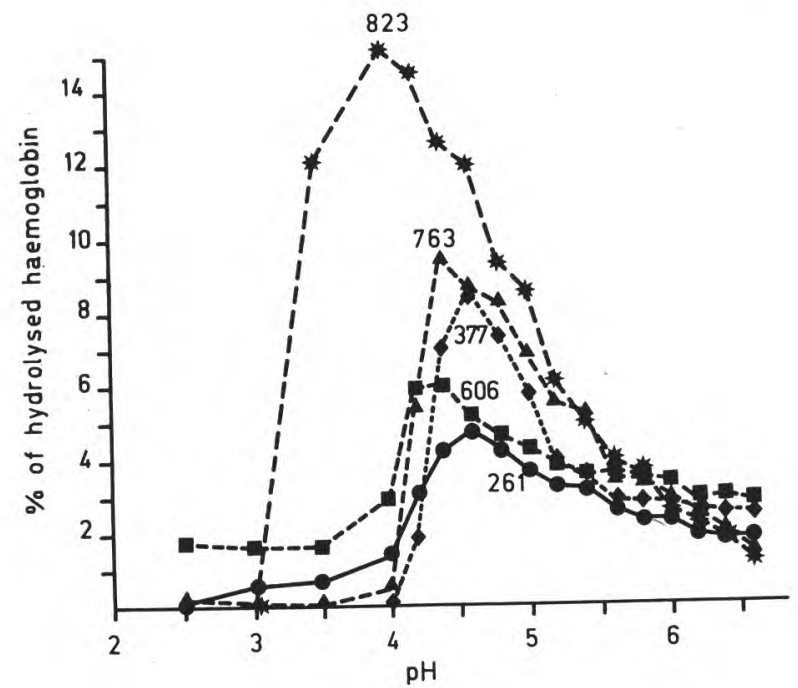

Fig. 2

pH optima at $35^{\circ} \mathrm{C}$ for the proteolytic activity of cell wall crude extracts from five strains of $\mathrm{S}$. lactis using ${ }^{14} \mathrm{C}$-haemoglobin as substrate.

pH optima d'activité protéolytique des extraits bruts de paroi des cinq souches de $\mathrm{S}$. lactis déterminés à $35^{\circ} \mathrm{C}$ en utilisant de la ${ }^{14} \mathrm{C}$-hémoglobine comme substrat. 


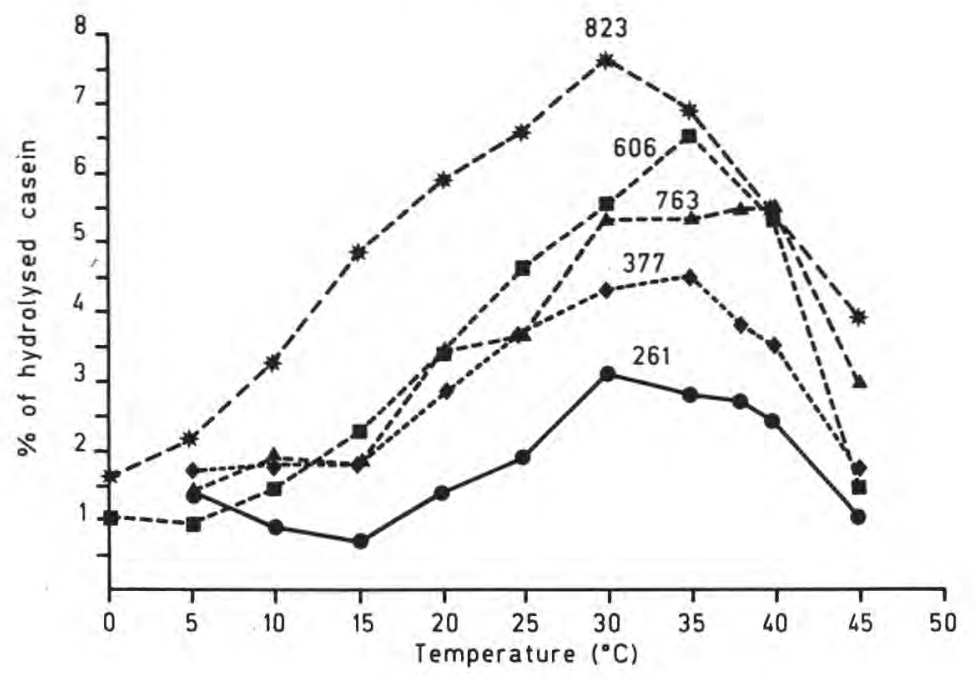

Fig. 3

Temperature optima at pH 6.0 for the proteolytic activity of cell wall crude extracts from five strains of $\mathrm{S}$. lactis using ${ }^{14} \mathrm{C}$-casein as substrate.

Température optima de l'activité protéolytique des extraits bruts de paroi des cinq souches de $\mathrm{S}$. lactis déterminés à $\mathrm{pH} 6$ en utilisant de la ${ }^{14} \mathrm{C}$-caséine comme substrat.

The action of the 5 cell-wall extracts on the main caseins $\left(\alpha_{\mathrm{s} 1}, \beta, \mathrm{K}\right)$ was analysed by electrophoresis after $2 \mathrm{~h}$ digestion at $\mathrm{pH} 6$ and $35^{\circ} \mathrm{C}$ (fig. 4 ). $\beta$-casein appeared to be the preferential substrate for all cell-wall extracts. This was also observed by EXTERKATE and DE VEER (1985) using a partially purified $S$. cremoris extract. The reduction of the $\beta$-casein band was marked and many breakdown products were visible; $\alpha_{\mathrm{s} 1}$ and $\mathrm{K}$ caseins were digested to a lower extent.

The electrophoretic patterns obtained with the 5 extracts were quite similar for each substrate. Patterns obtained with strains CNRZ 377, NCDO 606 and NCDO 763 were almost identical while those obtained with strains CNRZ 261 and NCDO 823 were somewhat different. In the case of strain CNRZ 261, this could be due to a low activity of the extract, leading to primary degradation products which may be degraded further by more active extracts. If this is the case, it is noteworthy that products with a low electrophoretic mobility proceeding from $\beta$-casein breakdown appeared later than the others. Two hypotheses may be put forward in the case of the extract from strain $S$. lactis subsp. diacetylactis NCDO 823, i.e. the hydrolysis was either stronger or sligthly different.

From the results mentioned above it may be assumed that the $4 \mathrm{~S}$. lactis strains under study have similar cell-wall associated proteolytic systems. Contrary to ExTERKATE studying S. cremoris (1975 and 1976), we have only found one single proteolytic activity in each of the tested strains. The homologies we have observed between the various extracts may be compared to the similitude 
TABLE II

Effect of several inhibitors ( $1 \mathrm{mM}$ final concentration) on the proteolytic activity of cell wall crude extracts from five stains of $\mathrm{S}$ lactis using ${ }^{14} \mathrm{C}$-casein as substrate, at $\mathrm{pH} 6.0$ and $35^{\circ} \mathrm{C}$

Action de différents inhibiteurs (concentration finale $1 \mathrm{mM}$ ) sur l'activité protéolytique des extraits bruts de paroi de 5 souches de $\mathrm{S}$. lactis déterminé en utilisant la ${ }^{14} \mathrm{C}$-caséine comme substrat, à pH 6 et à $35^{\circ} \mathrm{C}$

ND : inhibition $<10 \%$.

$D A N$ : diazoacetyl-norleucine methyl ester ; EDTA : ethylene diamine tetraacetic acid ; MIAA : mono iodoacetic acid ; PCMB : p-chloromercuribenzoic acid ; DTT : dithiothreitol: PMSF : phenylmethylsulfonide fluoride; DFP : diisopropylfluorophosphate ; TLCK : tosyl-lysine chloromethyl ketone ; TPCK : tosyl-phenylalanine chloromethyl ketone.

ND : inhibition $<10 \%$.

$D A N$ : diazoacétyl-norleucine méthyl ester ; EDTA : acide éthylène diamine tétraacétique ; MIAA : acide mono iodoacétique ; $P C M B$ : acide p-chloromercuribenzoïque ; DTT : dithiothréitol ; PMSF : phénylméthylsulfonide fluorure ; DFP : diisopropylfluorophosphate ; TLCK : tosyl-lysine chlorométhyl cétone; TPCK : tosyl-phénylalanine chlorométhyl cétone.

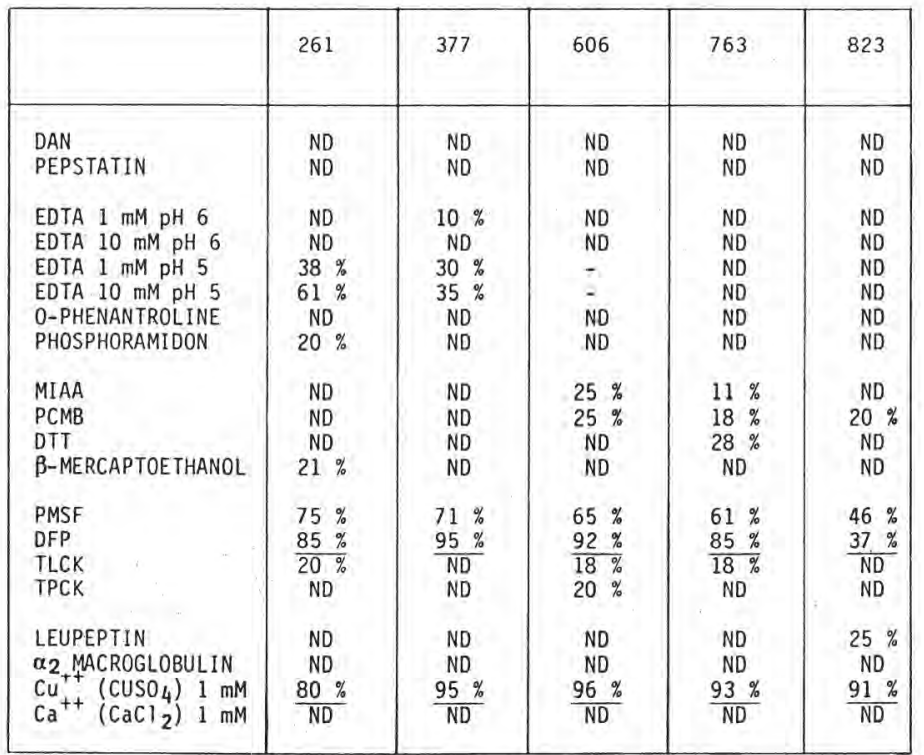

of casein breakdown patterns obtained in experimental Gouda cheeses which did not contain any active rennet and were manufactured with different $S$. cremoris strains (VISSER and DE GROOT-MOSTERT, 1977). The S. lactis subsp. diacetylactis NCDO 823 extract had many points in common with those of the $S$. lactis strains. However its $\mathrm{pH}$ optimum of activity on haemoglobin was slightly lower and the inhibition by DFP only partial suggesting the existence of some differences for this strain which does not belong to the same subspecie. 


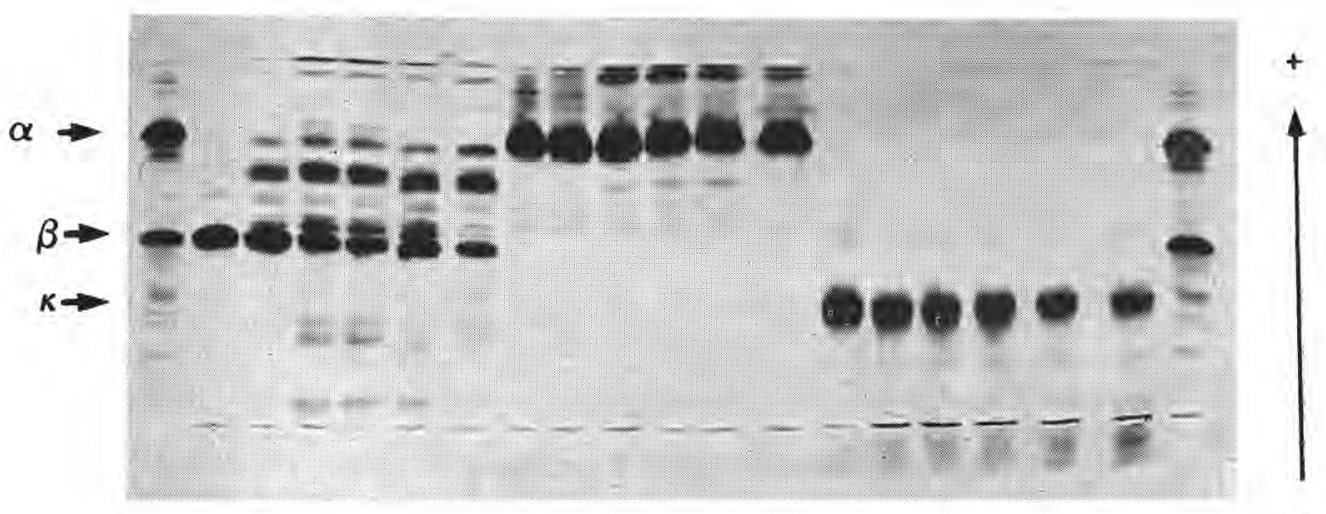

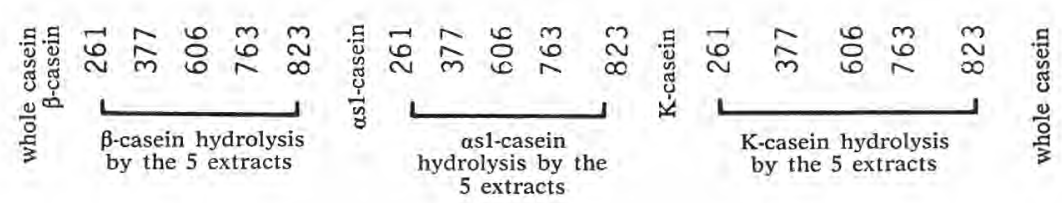

Fig. 4

Acrylamide-agarose gel electrophoresis of $\alpha_{\mathbb{S 1}}, \beta$ and $\mathrm{K}$-casein digests obtained with the five cell wall crude extracts. Digestions were carried out at $35^{\circ} \mathrm{C}, \mathrm{pH} 6.0$ for 2 hours.

Electrophorèses en gel d'acrylamide-agarose d'hydrolysats des caséines $\alpha_{\mathbb{S} 1}, \beta$ et $\mathbf{K}$ par les cinq extraits bruts de paroi. Les hydrolyses ont été effectuées à $35^{\circ} \mathrm{C}, p H$ pendant $2 \mathrm{~h}$.

\section{TABLE III}

Proteolytic activities of 3 successive extracts obtained from S. lactis NCDO 763 grown on 3 media : low-heat milk, UHT milk and M17. RUHT and RM17 values are the ratio between the proteolytic activity units obtained from the cells harvested from these media and those obtained from cells harvested from low-heat milk

Activités protéolytiques contenues dans les 3 extractions successives obtenues à partir de cellules de S. lactis NCDO 763 cultivées sur 3 milieux : lait "low-heat », lait UHT et milieu M17. RUHT et RM17 sont les rapports entre les unités d'activité protéolytique obtenues à partir de cellules cultivées sur lait UHT et milieu M17 et celles obtenues à partir de cellules cultivées sur lait «low-heat »

\begin{tabular}{|c|c|c|c|c|c|}
\hline $\begin{array}{c}\text { Extraction } \\
\text { number }\end{array}$ & $\begin{array}{c}\text { LOW-HEAT } \\
\text { MILK }\end{array}$ & $\begin{array}{c}\text { U.H.T. } \\
\text { MILK }\end{array}$ & R.U.H.T. & $\begin{array}{l}\text { M17 }+\mathrm{Ca}^{++} 5 \mathrm{mM} \\
\text { Medium }\end{array}$ & RM17 \\
\hline 1 & $1 \mathrm{U} / 10^{9} \phi$ & $0,4 \mathrm{U} / 10^{9} \phi$ & 2,5 & $0,3 \mathrm{U} / 10^{9} \phi$ & 3,3 \\
2 & $2,6 \mathrm{U} / 10^{9} \phi$ & $1,4 \mathrm{U} / 10^{9} \phi$ & 1,8 & $0,5 \mathrm{U} / 10^{9} \phi$ & 5,2 \\
3 & $1,8 \mathrm{U} / 10^{9} \phi$ & $1,5 \mathrm{U} / 10^{9} \phi$ & 1,2 & $0,2 \mathrm{U} / 10^{9} \phi$ & 9 \\
$\bar{M}$ & $1,7 \mathrm{U} / 10^{9} \phi$ & $1,1 \mathrm{U} / 10^{9} \phi$ & 1,8 & $0,3 \mathrm{U} / 10^{9} \phi$ & 5,8 \\
\hline
\end{tabular}




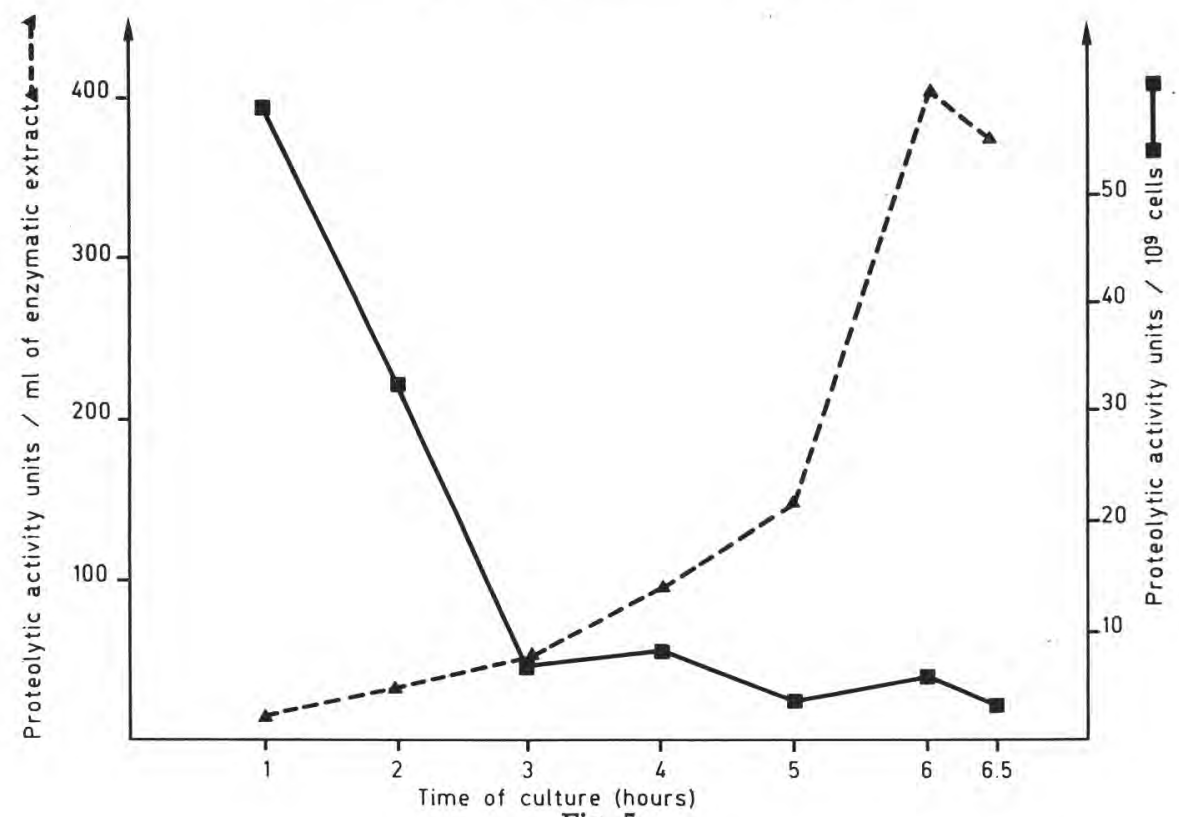

Fig. 5

Production of cell wall proteolytic activity by S. lactis NCDO 763 cells during their growth on low-heat milk

total proteolytic activity units.

Production de l'activité protéolytique de paroi par les cellules de S. lactis NCDO 763 pendant leur croissance sur lait "low-heat "

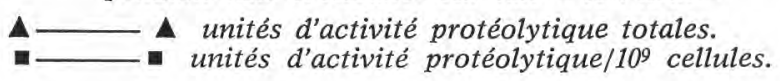

\section{Proteinase production}

The amount of cell-wall proteinase produced on milk being rather small, one of the strains (S. lactis NCDO 763) was grown on two other media easier for high volume culture and allowing a good cell growth : UHT milk, and M17 medium admixed with $5 \mathrm{mM} \mathrm{CaCl}$, required for the accumulation of proteinases in the cell-wall (EXTERKATE, 1979). The use of a higher calcium concentration led to precipitation of the medium.

Table III shows the proteolytic activity recovered during 3 successive extractions from cells grown on the 3 media. RUTH and RM17 ratios show that cells grown on UHT milk produced almost 2 -fold less enzyme than cells grown on low-heat milk while the amount produced on M17 was 5 times lower.

Two factors may account for these differences:

- On one hand, the amount of peptides in the medium; it was indeed noticed that the proteinase production decreased when cells were grown on a 
medium including more peptides than the low-heat milk used as a control. The high peptide content of M17 and the fact that commercial UHT milk contains at least $8 \%$ additional non protein nitrogen (due to the heat treatment) as compared to low-heat milk (ALAIS, 1984) may explain our results. Our observations are in keeping with the hypothesis of EXTERKATE (1985) concerning the inhibition of cell-wall proteinase synthesis in the case of an excessive supply of amino acids and peptides in the culture medium.

- On the other hand, the calcium concentration of the medium which was only $5 \mathrm{mM}$ in M17 whereas it was $32 \mathrm{mM}$ in the milk.

The influence of physiological cell age on cell-wall proteinase production was investigated during bacterial growth on milk (fig. 5). It appeared that the proteolytic activity released by the cells increased with culture time. However, it remained lower than 40 units $/ \mathrm{ml}$ of enzymatic extract during the first $3 \mathrm{~h}$ whereafter it rapidly increased to $400 \mathrm{units} / \mathrm{ml}$ of extract after $6 \mathrm{~h}$ of culture. On the other hand, the shape of the curve representing the number of proteolytic units released per $10^{9}$ cells as a function of time was different in these 2 periods. Thus, during the first $3 \mathrm{~h}$ the values decreased from 57 to 7 units $/ 10^{9}$ cells whereafter they became stabilised between 3 and 8 units $/ 10^{9}$ cells. It may be assumed that during early culture the cells have to produce proteinases capable of releasing enough peptides for their growth requirements, the medium (milk) being poor in peptides. The bacterial multiplication leading to a higher peptide production, the amount of synthetised proteinases will then be adjusted according to the number of bacteria and their nitrogen requirements.

Reçu le 4 juin 1986

Accepté pour publication le 4 septembre 1986

\section{Acknowledgements}

The authors are grateful to Bruno RIBADEAU-DUMAS for helpful discussions and to Kirstsen RERAT for her assistance in the preparation of the manuscript.

\section{Références bibliographiques}

AlaIs C., 1984. Science du lait. Principe des techniques laitières. $4^{e}$ édition, Sepaic, Paris.

BRADFORD M.M., 1976. A rapid and sensitive method for quantitation of microgram quantities of protein utilizing the principle of dye-binding. Anal. Biochem., 72, 248-254.

CLIFFE A.J., LAW B.A., 1985. Discontinuous polyacrylamide gel electrophoresis of cell wall proteinases from variants of Streptococcus lactis. J. Appl. Bacteriol., 58, 245-250.

DONNELLY W.J., BARRY J.G., RICHARDSON Y., 1980. ${ }^{14}$ C-methylated casein as a substrate for plasmin and its application to the study of milk protein transformations. Biochim. Biophys. Acta, 626, 117-126.

EXTERKATE F.A., 1975. An introductory study of the proteolytic system of Streptococcus cremoris strain HP. Neth. Milk Dairy J., 29, 303-318. 
EXTERKATE F.A., 1976. Comparison of strains of Streptococcus cremoris for proteolytic activities associated with the cell wall. Neth. Milk Dairy J., 30, 95-105.

EXTERKATE F.A., 1979. Accumulation of proteinase in the cell wall of Streptococcus cremoris strain AM1 and regulation of its production. Arch. Microbiol., 120, 247-254.

EXTERKATE F.A.r 1985. A dual-directed control of cell wall proteinase production in Streptococcus cremoris AM1 : a possible mechanism of régulation during growth in milk. J. Dairy Sci., 68, 562-571.

Exterkate F.A., DE Veer G.J.C.M., 1985. Partial isolation and degradation of caseins by cell wall proteinase(s) of Streptococcus cremoris HP. Appl. Environ. Microbiol., 49, 328-332.

Geis A., BockelmanN W., Teuber M., 1985. Simultaneous extraction and purification of a cell wall associated peptidase and $\beta$-casein specific protease from Streptococcus cremoris AC1. Appl. Microbiol. Biotechnol., 23, 79-84.

Gripon J.C., Desmazeaud M.J., Le Bars D., Bergere J.L., 1975. Etude du rôle des microorganismes et des enzymes au cours de la maturation des fromages. II. Influence de la présure commerciale. Lait, 548, 502-516.

HUgenholtz J., EXteRKate F.A., Konings W.N., 1984. The proteolytic system of Streptococcus cremoris : an immunological analysis. Appt. Environ. Microbiol., 48, 1105-1110.

MILLS O.E., Thomas T.D., 1978. Release of cell wall associated proteinase(s) from lactic Streptococci. N.Z.J. Dairy Sci. Technol., 13, 209-215.

MILLS O.E., Thomas T.D., 1980. Bitterness development in Cheddar cheese : Effect of the level of starter proteinase. N.Z.J. Dairy Sci. Technol., 13, 209-215.

MONNET V., LE BARS D., GRIPON J.C., 1986. Purification and characterization of a cell wall proteinase from Streptococcus lactis NCDO 763. J. Dairy Res., (accepted for publication).

Terzaghi B.E., SANDINE W.E., 1975. Improved medium for lactic streptococci and their bacteriophages. Appl. Microbiol., 29, 807-813.

THOMAS T.D., JARVIS B.D.W., SKIPPER N.A., 1974. Localization of proteinase(s) near the cell surface of Streptococcus lactis. J. Bacteriol., 118, 329-333.

Thomas T.D., 1975. Tagatose 1-6 diphosphate activation of lactate deshydrogenase from Streptococcus cremoris. Biochem. Biophys. Res. Commun., 63, 1035-1042.

THOMAS T.D., TURNER K.W., 1977. Preparation of skim milk to allow harvesting of starter cells from milk cultures. N.Z.I. Dairy Sci. Technol., 12, 15-21.

Thomas T.D., Mills O.E., 1981. Proteolytic enzymes of starter bacteria. Neth. Milk Dairy J., $35,255-273$.

URIEL J., 1966. Méthode d'électrophorèse dans des gels d'acrylamide agarose. Bull. Soc. Chim. Biol., 48, 969-982.

Visser F.M.W., DE GRoot-Mostert A.E.A., 1977. Contribution of enzymes from rennet, starter bacteria and milk to proteolysis and flavour development in Gouda cheese. 4. Protein breakdown : a gel electrophoretical study. Neth. Milk Dairy J., 31, 247-264. 